\title{
EFFECT OF VERTICAL DISCONTINUITY OF COLUMNS IN R.C FRAMES SUBJECTED TO DIFFERENT WIND SPEEDS IN INDIA
}

\author{
M. Pavan Kumar ${ }^{1}$, Singuri Sirisha ${ }^{2}$ \\ ${ }^{1}$ Asst. Professor, Department of Civil Engineering, SVP Engineering College, Andhra Pradesh, India \\ ${ }^{2}$ M.E, Department of Civil Engineering, SVP Engineering College, Andhra Pradesh, India
}

\begin{abstract}
Majority of structural systems are designed with various levels of irregularities in accordance with architectural requirements in order to produce aesthetic buildings. Irregular structures come into being due to discontinuity in mass, stiffness and strength in elevation and due to asymmetric geometrical conCharturation on plane. One of the irregularities in elevation is discontinuity of columns. In the present study, effects of the structural irregularity which is produced by the discontinuity of a columns in RC space frames subjected to different wind loads was investigated. Investigation was carried out for R.C space frames, with and without vertical discontinuity of columns for $G+5, G+10 \& G+15$ storeys, assumed to be located in different wind zones in India. Both regular and irregular structures were analysed using STAADPro. From the study, it was concluded that frames without vertical discontinuity of the columns having more stiffness when compared to frames with vertical discontinuity of columns.
\end{abstract}

Keywords: Structural irregularity, Vertical discontinuity, Discontinuity of columns, Wind loads.

$* * *$

\section{INTRODUCTION}

The buildings can be broadly categorized as regular and irregular buildings. In the present day scenario, irregular buildings are given more preference due to a variety of reasons. The aesthetic considerations, space availability and user requirement are the most important reasons for preference of irregular buildings. An irregular building can be defined as a building that lacks symmetry and has discontinuity in geometry, mass or load resisting elements. The presence of structural irregularities has an adverse effect on the wind load response of the structure. The structural irregularities can be broadly categorized as horizontal and vertical irregularity, and different types of irregularities have different types of effects on the structure. Many urban multistorey buildings in India today have open storeys at lower floors [i.e.at two or three floors at bottom] this is primarily being adopted to accommodate commercial complex at those floors and remaining above floors serve for residential building which leads to vertical discontinuity and effects the building for an early failure.

Studies aimed to predict the behaviour of structures with vertical irregularities against wind loads are small in number compared to the studies aimed to predict the behaviour of structures with vertical irregularities of columns and horizontal irregularity. Nevertheless, in recent years research activity in this field has been growing. Researchers Sarkar[10], Duana[11], Poonam[12] and others have a lot of studies for the effects of vertical irregularities on the seismic behaviour of structures so that, in this study only wind loads are considered to find out the displacements.

\subsection{Objectives of the Study:}

Two models of Reinforced Concrete structures with and without vertical discontinuity of columns for $\mathrm{G}+15$ stories at different wind speeds (i.e, $33 \mathrm{~m} / \mathrm{s}, 39 \mathrm{~m} / \mathrm{s}, 44 \mathrm{~m} / \mathrm{s}, 47 \mathrm{~m} / \mathrm{s}$, $50 \mathrm{~m} / \mathrm{s}$ and $55 \mathrm{~m} / \mathrm{s}$ ) were considered and analysed. Main objectives of the present work as follows:

- To study the influence of vertical discontinuity of columns on R.C space frames subjected to wind loads at different wind zones in India.

- To determine the percentage variation of displacements of considered R.C space frames at different wind speeds for $\mathrm{G}+5, \mathrm{G}+10 \& \mathrm{G}+15$ stories.

- $\quad$ To determine the percentage variation of quantity of steel of considered frames $\mathrm{G}+5, \mathrm{G}+10 \& \mathrm{G}+15$ stories levels at different wind speeds.

\section{LITERATURE REVIEW}

Studies aimed to predict the behavior of structures with vertical irregularities against wind loads are small in number compared to the studies aimed to predict the behaviour of structures with vertical irregularities of columns and horizontal irregularity. Nevertheless, in recent years research activity in this field has been growing. Researchers have a lot of studies for the effects of vertical irregularities on the seismic behaviour of structures so that, in this study only wind loads are considered to find out the displacements. These irregularities are characterised by vertical discontinuities in the distributions of masses, stiffness and strengths. For the next paragraphs some studies that consider vertical irregularity associated with setbacks of the structure or stopping of the core wall at different levels of the structure are listed below: Shahrooz and Moehle $(1990)^{[14]}$ undertook an experimental and analytical study to 
understand the earthquake response of setback structures. The experimental study involved design, construction, and earthquake simulation testing of a quarter- scale model of a multistory, reinforced concrete, setback frame. The analytical studies involved design and inelastic analysis of several multistory frames having varying degrees of setbacks. Among the issues addressed were:(1) The influence of setbacks on dynamic response; (2) The adequacy of current static and dynamic design requirements for setback buildings; and (3)Design methods to improve the response of setback buildings. Valmundsson and $\mathrm{Nau}$ $(1997)^{[15]}$ investigated the appropriateness of provisions for considering different irregularities as laid in the Uniform Building Code (UBC). They considered twodimensional building frames with heights of 5, 10 and 20 storeys, assuming the beams to be stiffer than the columns. For each structure height, uniform structures were defined to have constant mass of $35 \mathrm{Mg}$, and stiffnesses were calculated to give a set of 6 desired fndamental periods. The maximum calculated drifts from the lateral design forces for the regular structures having the target period were found to lie within the UBC limit. Mass irregularities at three locations in the elevation of structures were then applied by means of mass ratios (ratio of modified mass of irregular case to the mass of uniform structure at a floor level) ranging between 0.1 and 5, and responses were calculated for design ductility's of $1,2,6$, and 10 considering four earthquake records. The increase in ductility demand was found to be not greater than $20 \%$ for a mass ratio of 1.5 and mass discontinuity was most critical when located on lower floors. Mass irregularity was found to be least important of the irregularity effects.Das $(2000)^{[2]}$ found that most of the structures designed by ELF method performed reasonably well. Capacity based criteria must be appropriately applied in the vicinity of the irregularity.Michalis et. al (2006) ${ }^{[10]}$ carried out incremental dynamic analyses on a realistic LA9 nine storey steel frame to evaluate the effect of irregularities for each performance level, from serviceability to global collapse. A mass ratio of 2 was applied at series of locations over the selected frame and effects of mass irregularity were evaluated. It was found that the influence of mass irregularity on interstorey drifts was comparable to the influence of stiffness irregularity.Lee and Kee (2007) ${ }^{[9]}$ subjected three 1:12 scale 17-story RC wall building models having different types of irregularity at the bottom two stories to the same series of simulated earthquake excitations to observe their seismic response characteristics. The first model had a symmetrical moment-resisting frame (Model 1), the second had an infilled shear wall in the central frame (Model 2), and the third had an infilled shear wall in only one of the exterior frames (Model 3) at the bottom two stories. The total amounts of energy absorption by damage are similar regardless of the existence and location of the infilled shear wall. The largest energy absorption was due to overturning, followed by the shear deformation. Sadjadi et al. $(2007)^{[12]}$ presented an analytical approach for seismic assessment of RC frames using nonlinear time history analysis and push-over analysis. The analytical models were validated against available experimental results and used in a study to evaluate the seismic behavior of these 5-story frames. Athanassiadou $(2008)^{[1]}$ concluded that the effect of the ductility class on the cost of buildings is negligible, while performance of all irregular frames subjected to earthquake appears to be equally satisfactory, not inferior to that of the regular ones, even for twice the design earthquake forces. DCM frames were found to be stronger and less ductile than the corresponding DCH ones. The over strength of the irregular frames was found to be similar to that of the regular ones, while DCH frames were found to dispose higher over strength than DCM ones. Pushover analysis seemed to underestimate the response quantities in the upper floors of the irregular frames.Karavallis et al. $(2008)^{[8]}$ studied the inelastic seismic response of plane steel moment-resisting frames with vertical mass irregularity. The analysis of the created response databank showed that the number of storeys, ratio of strength of beam and column and the location of the heavier mass influence the height-wise distribution and amplitude of inelastic deformation demands, while the response does not seem to be affected by the mass ratio.Sarkar et al. (2010) $)^{[13]}$ proposed a new method of quantifying irregularity in vertically irregular building frames, accounting for dynamic characteristics (mass and stiffness). The salient conclusions were as follows: (1)A measure of vertical irregularity, suitable for stepped buildings, called _regularity index', is proposed, accounting for the changes in mass and stiffness along the height of the building. (2) An empirical formula is proposed to calculate the fundamental time period of stepped building, as a function of regularity index.Duana et al. (2012) ${ }^{[3]}$ According to the numerical results, the structures designed by GB50011-2010 provides the inelastic behavior and response intended by the code and satisfies the inter-storey drift and maximum plastic rotation limits recommended by ASCE/SEI 41-06. The push-over analysis indicated the potential for a soft first story mechanism under significant lateral demands. Poonam et al. (2012) ${ }^{[11]}$ - Results of the numerical analysis showed that any storey, especially the first storey, must not be softer/weaker than the storeys above or below. Irregularity in mass distribution also contributes to the increased response of the buildings. The irregularities, if required to be provided, need to be provided by appropriate and extensive analysis and design processes. Although the above researchers and few others have given useful insights into the topic of vertical irregularities and their effects on structural response against seismic analysis, but these studies are not carried out against wind analysis. For that reason, in this thesis work an attempt is made to determine the percentage variation of displacements in frames with vertical discontinuity and without vertical discontinuity at variable wind speeds for different zones in India.

\section{METHODOLOGY}

A regular RC frame structure is chosen with and without vertical discontinuity of columns, the plan of the apartment shown in Chart.1\&2 and the structure was modeled for $\mathrm{G}+5$, $\mathrm{G}+10 \& \mathrm{G}+15$ stories. The overall plan dimension of RC frame structures is $42.59 \mathrm{~m} \times 35.79 \mathrm{~m}$. All the considered frames are assumed to be fixed at ground level and storey heights are taken as $3 \mathrm{~m}$. All the members of the structure are 
assumed to be homogeneous isotropic and having elastic modulus same in compression as well as in tension. Constant beam and columns sizes were taken at all floors levels for each considered frame, however sizes of columns and beams vary with respect to number of storeys. Sizes of structural members shown in tables given below:

Table -1: Section Details

\begin{tabular}{|c|c|}
\hline Member & Size (mm) \\
\hline Beams & $300 \times 450$ \\
\hline Columns & $300 \times 900$ \\
\hline Slab & 150 \\
\hline
\end{tabular}

Table -2: Dead Loads

\begin{tabular}{|c|c|}
\hline Load Type & Intensity $\left(\mathbf{k N} / \mathbf{m}^{\mathbf{2}}\right)$ \\
\hline Floor Finish & 0.75 \\
\hline Unexpected partition & 1.0 \\
\hline
\end{tabular}

Table -3: Live Loads

\begin{tabular}{|c|c|}
\hline Load Type & Intensity $\left(\mathbf{k N} / \mathbf{m}^{\mathbf{2}}\right)$ \\
\hline All internal rooms & 2.0 \\
\hline Staircase and Corridor & 3.0 \\
\hline
\end{tabular}

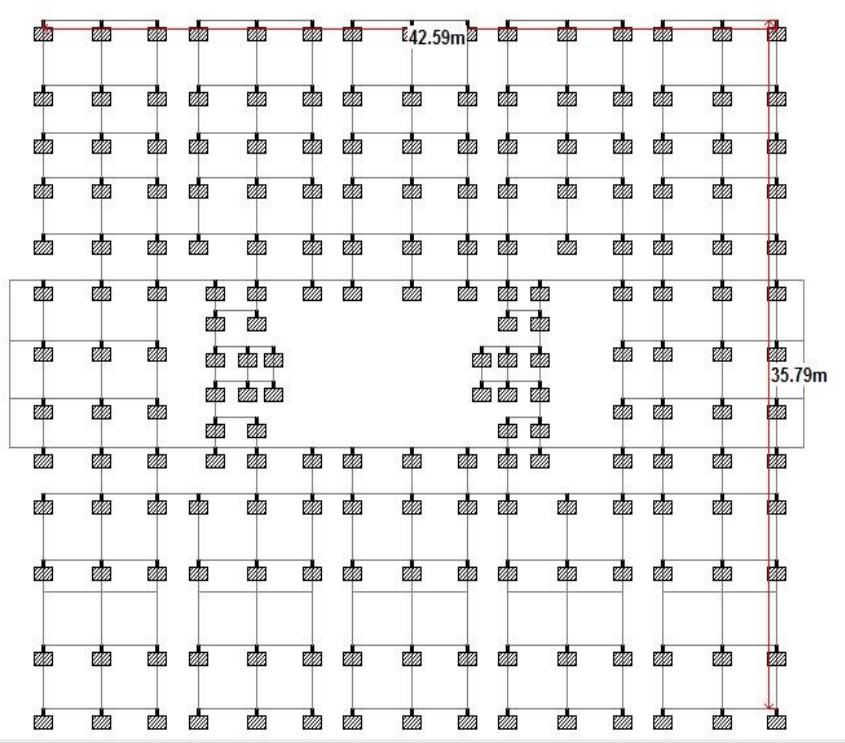

Fig.1: Plan showing apartment with vertical discontinuity of columns.

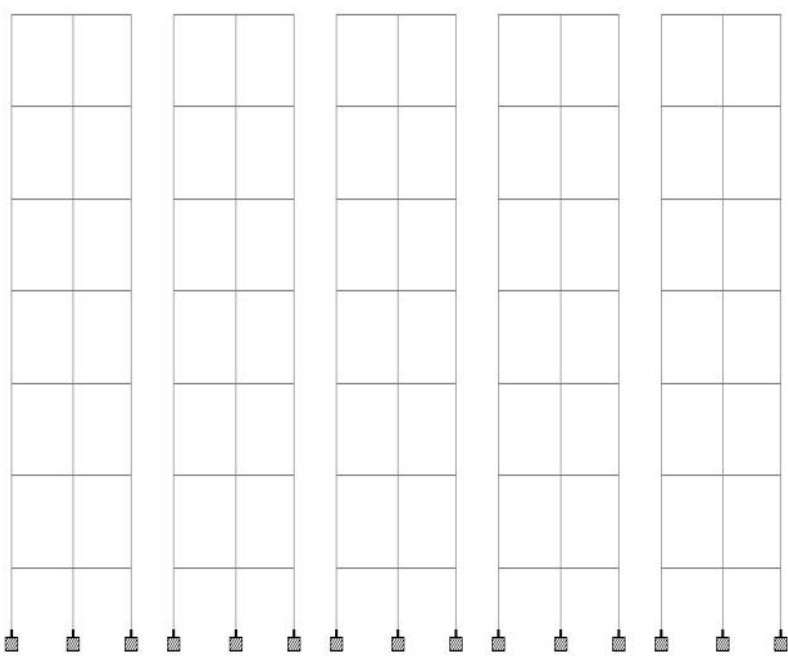

Fig.2: Elevation showing apartment with vertical discontinuity of columns.

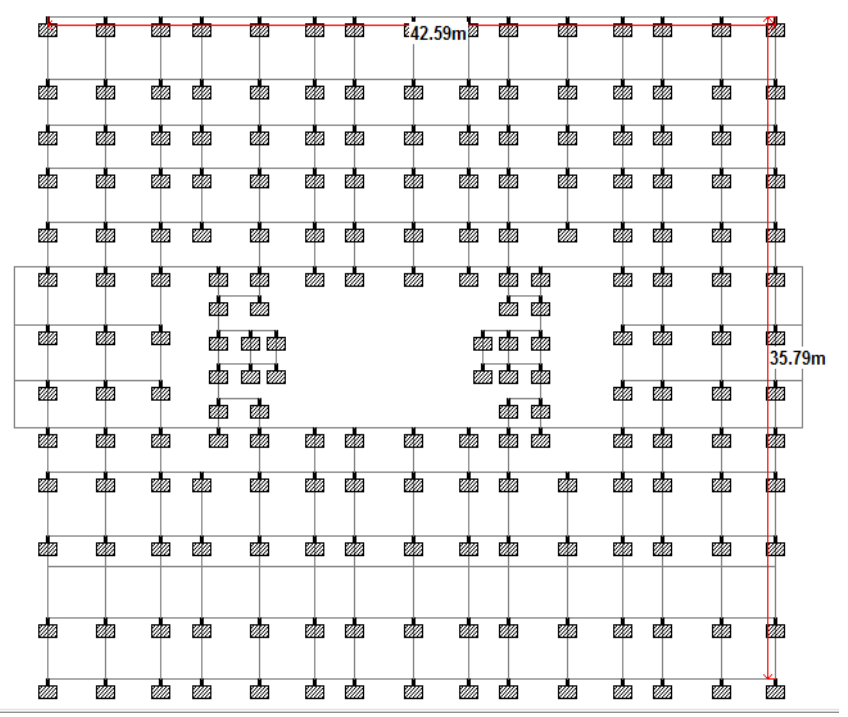

Fig.3: Plan showing apartment without vertical discontinuity of columns.

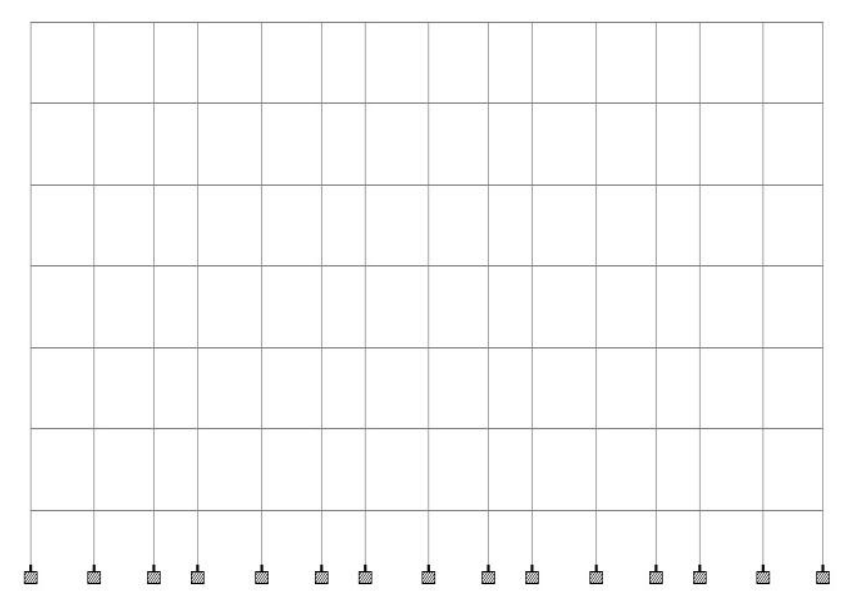

Fig.4: Elevation showing apartment without vertical discontinuity of columns. 


\section{RESULTS AND DISCUSSIONS}

\subsection{Frames without Vertical Discontinuity}

A frame of G+15 stories without vertical discontinuity of columns has been considered and Graphs were plotted for Displacements Vs Height at different wind speeds.

\subsubsection{Case i(a): Wind Speed at $33 \mathrm{~m} / \mathrm{sec}$.}

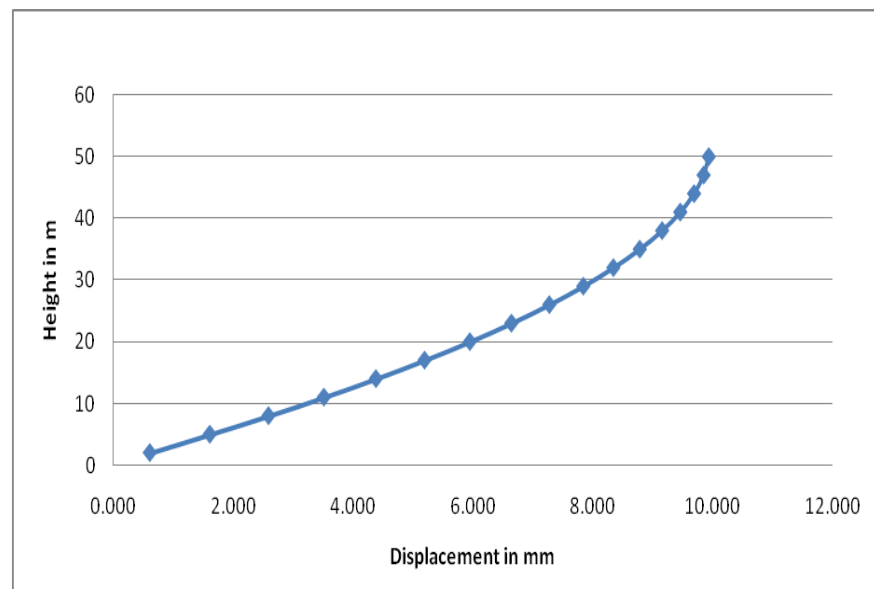

Chart-1: Displacements Vs Height for G+ 15 frame without vertical discontinuity of columns at $33 \mathrm{~m} / \mathrm{sec}$ wind speed

From the Chart-1, it was observed that maximum displacement of $9.933 \mathrm{~mm}$ occurs at top storey. It satisfied the requirement of permissible displacement (i.e., $\mathrm{H} / 500, \mathrm{H}$ $=$ Height of the structure) as per IS456:2000

\subsubsection{Case i(b): Wind Speed at $39 \mathrm{~m} / \mathrm{sec}$.}

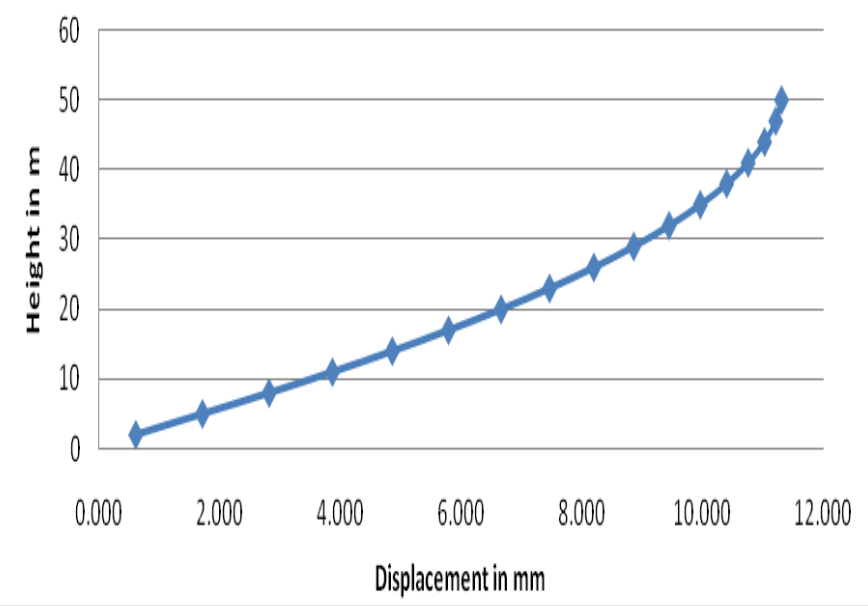

Chart-2: Displacements Vs Height for G+ 15 frame without vertical discontinuity of columns at $39 \mathrm{~m} / \mathrm{sec}$ wind speed

From the Chart-2, it was observed that maximum displacement of $11.308 \mathrm{~mm}$ occurs at top storey. It satisfied the requirement of permissible displacement (i.e., $\mathrm{H} / 500, \mathrm{H}$ $=$ Height of the structure) as per IS456:2000

\subsubsection{Case i(c): Wind Speed at $44 \mathrm{~m} / \mathrm{sec}$.}

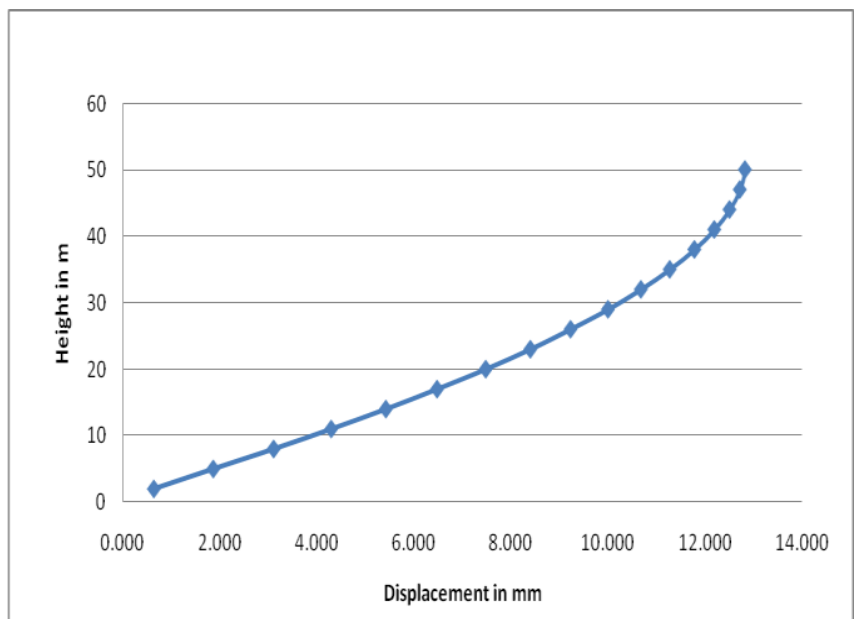

Chart-3: Displacements Vs Height for G+ 15 frame without vertical discontinuity of columns at $44 \mathrm{~m} / \mathrm{sec}$ wind speed

From the Chart-3, it was observed that maximum displacement of $12.830 \mathrm{~mm}$ occurs at top storey. It satisfied the requirement of permissible displacement (i.e., H/500, $\mathrm{H}$ $=$ Height of the structure) as per IS456:2000

\subsubsection{Case i(d): Wind Speed at $47 \mathrm{~m} / \mathrm{sec}$.}

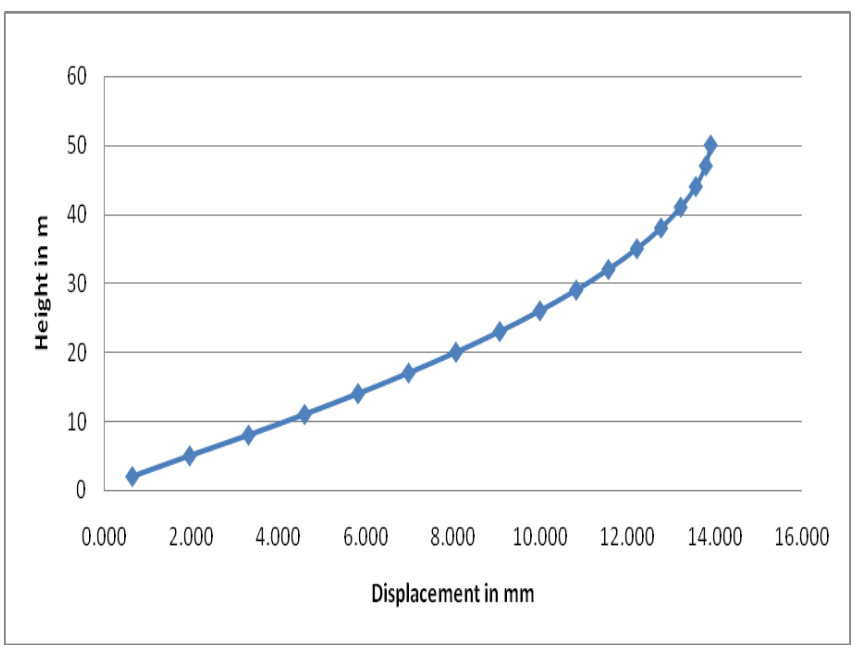

Chart-4: Displacements Vs Height for G+ 15 frame without vertical discontinuity of columns at $47 \mathrm{~m} / \mathrm{sec}$ wind speed

From the Chart-4, it was observed that maximum displacement of $13.906 \mathrm{~mm}$ occurs at top storey. It satisfied the requirement of permissible displacement (i.e., H/500, H $=$ Height of the structure) as per IS456:2000 


\subsubsection{Case i(e): Wind Speed at $50 \mathrm{~m} / \mathrm{sec}$.}

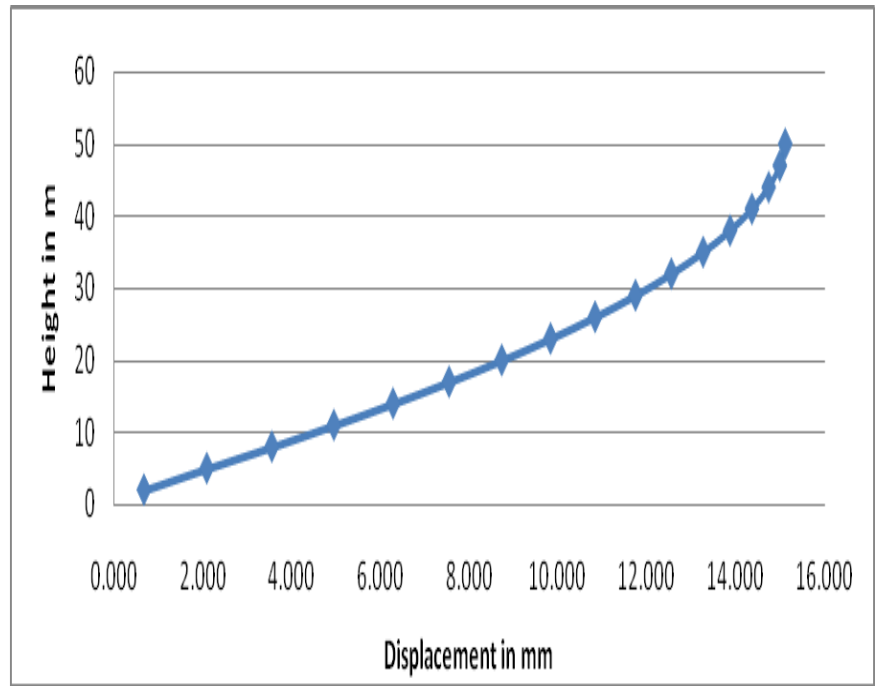

Chart-5: Displacements Vs Height for G+ 15 frame without vertical discontinuity of columns at $50 \mathrm{~m} / \mathrm{sec}$ wind speed

From the Chart-5, it was observed that maximum displacement of $15.106 \mathrm{~mm}$ occurs at top storey. It satisfied the requirement of permissible displacement (i.e., H/500, H $=$ Height of the structure) as per IS456:2000

\subsubsection{Case i(f): Wind Speed at $55 \mathrm{~m} / \mathrm{sec}$.}

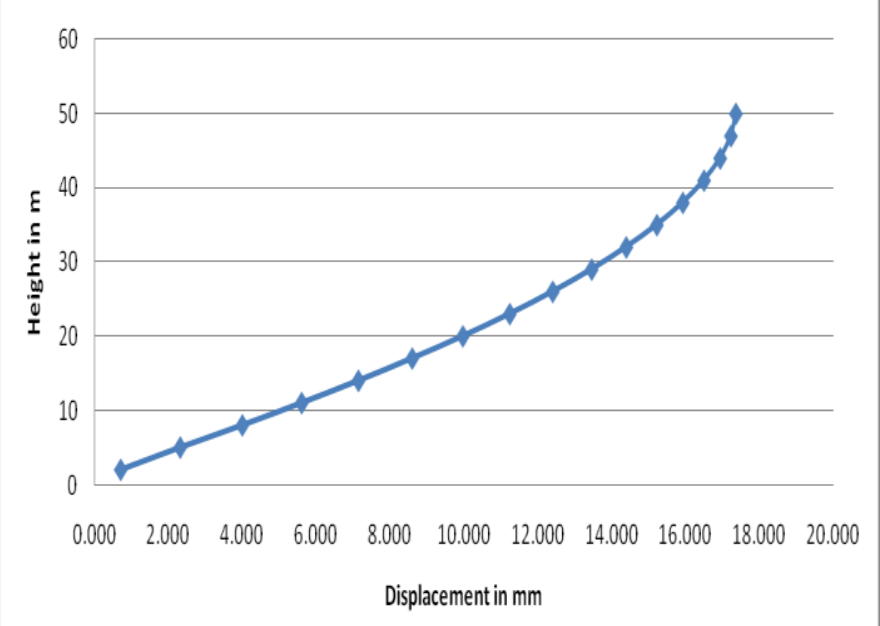

Chart-6: Displacements Vs Height for G+ 15 frame without vertical discontinuity of columns at $55 \mathrm{~m} / \mathrm{sec}$ wind speed

From the Chart-6, it was observed that maximum displacement of $17.364 \mathrm{~mm}$ occurs at top storey. It satisfied the requirement of permissible displacement (i.e., $\mathrm{H} / 500, \mathrm{H}$ $=$ Height of the structure) as per IS456:2000

\subsection{Frames with Vertical Discontinuity}

A frame of $\mathrm{G}+15$ stories with vertical discontinuity of columns has been considered and Graphs were plotted for Displacements Vs Height at different wind speeds.

\subsubsection{Case ii (a): Wind Speed at $33 \mathrm{~m} / \mathrm{sec}$.}

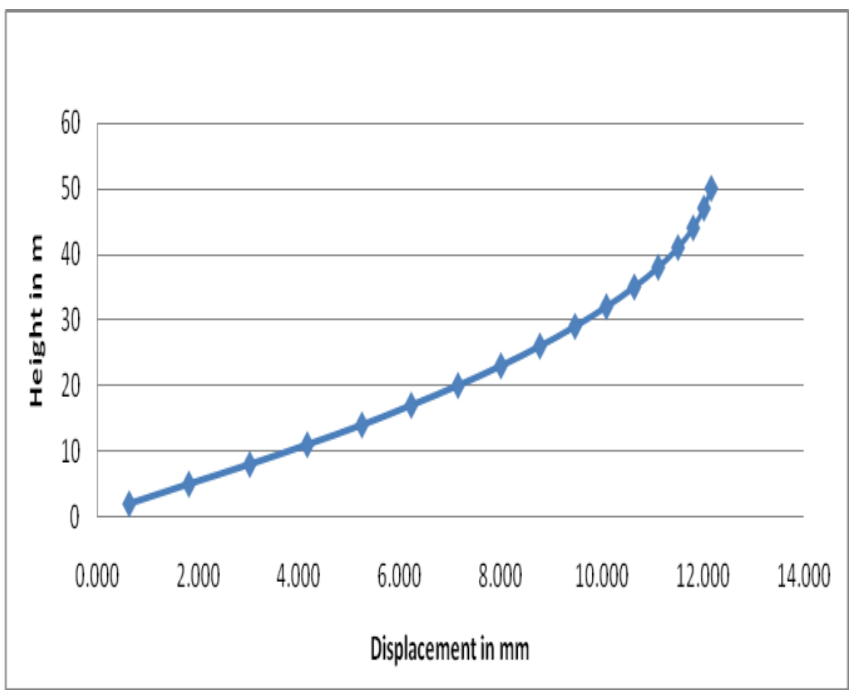

Chart-7: Displacements Vs Height for G+ 15 frame with vertical discontinuity at $33 \mathrm{~m} / \mathrm{sec}$ wind speed

From the Chart-7, it was observed that maximum displacement of $12.173 \mathrm{~mm}$ occurs at top storey. It satisfied the requirement of permissible displacement (i.e., H/500, H $=$ Height of the structure) as per IS456:2000

\subsubsection{Case ii (b): Wind Speed at $39 \mathrm{~m} / \mathrm{sec}$.}

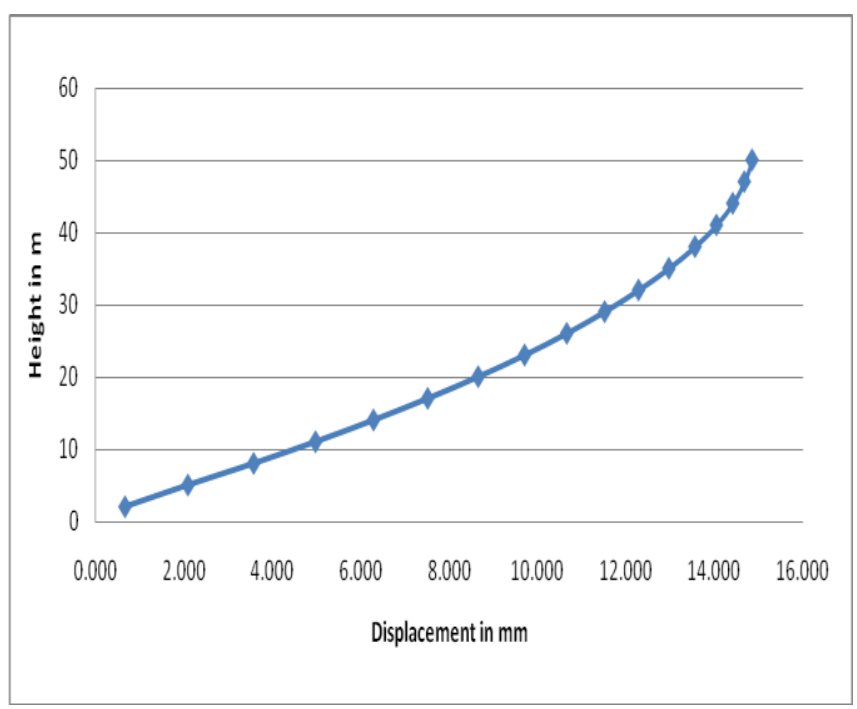

Chart-8: Displacements Vs Height for G+ 15 frame with vertical discontinuity at $39 \mathrm{~m} / \mathrm{sec}$ wind speed

From the Chart-8, it was observed that maximum displacement of $14.855 \mathrm{~mm}$ occurs at top storey. It satisfied the requirement of permissible displacement (i.e., $\mathrm{H} / 500, \mathrm{H}$ $=$ Height of the structure) as per IS456:2000 


\subsubsection{Case ii (c): Wind Speed at $44 \mathrm{~m} / \mathrm{sec}$.}

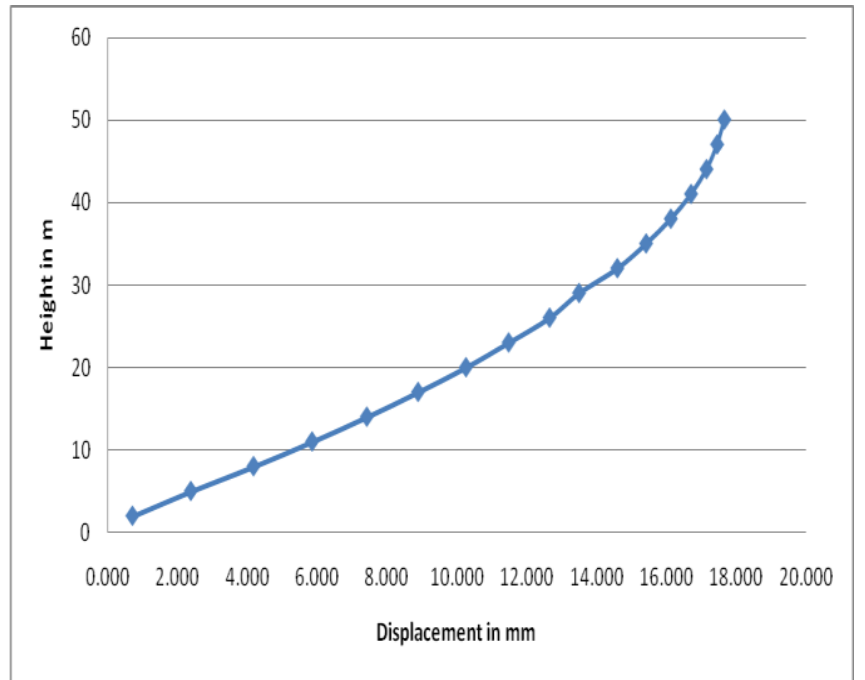

Chart-9: Displacements Vs Height for G+ 15 frame with vertical discontinuity at $44 \mathrm{~m} / \mathrm{sec}$ wind speed

From the Chart-9, it was observed that maximum displacement of $17.657 \mathrm{~mm}$ occurs at top storey. It satisfied the requirement of permissible displacement (i.e., H/500, H $=$ Height of the structure) as per IS456:2000

\subsubsection{Case ii (d): Wind Speed at $47 \mathrm{~m} / \mathrm{sec}$.}

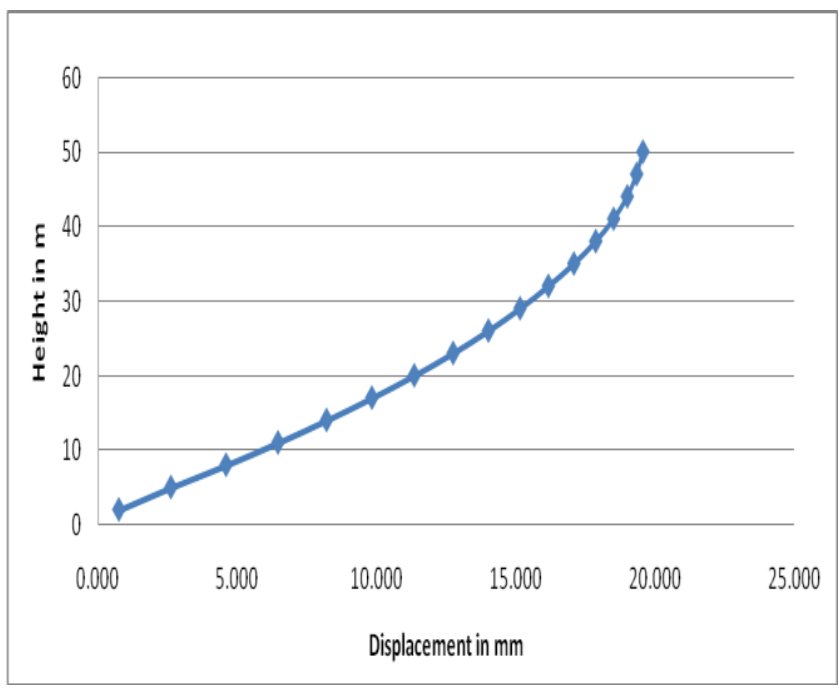

Chart-10: Displacements Vs Height for G+ 15 frame with vertical discontinuity at $47 \mathrm{~m} / \mathrm{sec}$ wind speed

From the Chart-10, it was observed that maximum displacement of $19.572 \mathrm{~mm}$ occurs at top storey. It satisfied the requirement of permissible displacement (i.e., H/500, H $=$ Height of the structure) as per IS456:2000

\subsubsection{Case ii (e): Wind Speed at $50 \mathrm{~m} / \mathrm{sec}$.}

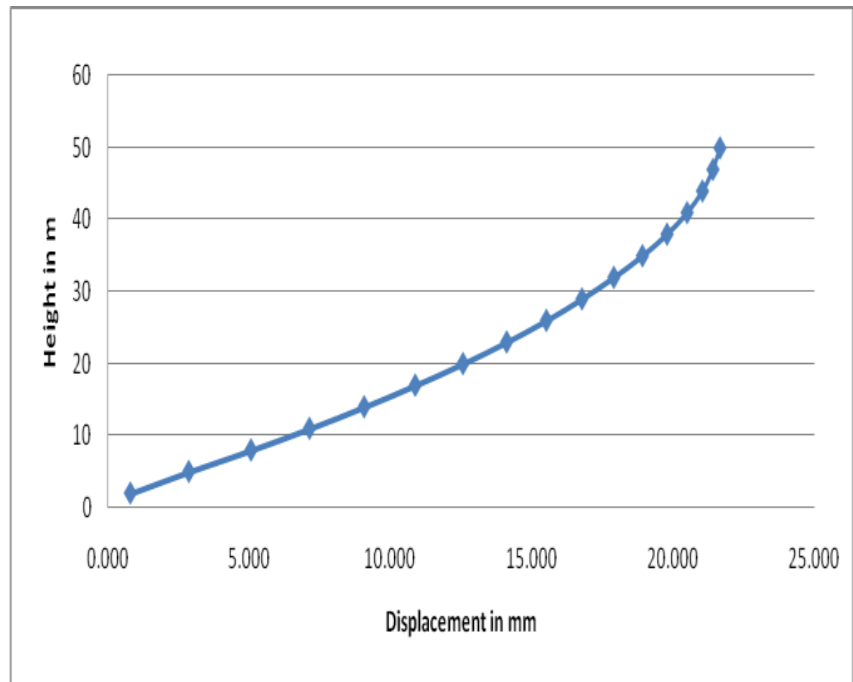

Chart-11: Displacements Vs Height for G+ 15 frame with vertical discontinuity at $50 \mathrm{~m} / \mathrm{sec}$ wind speed

From the Chart-11, it was observed that maximum displacement of $21.664 \mathrm{~mm}$ occurs at top storey. It satisfied the requirement of permissible displacement (i.e., H/500, $\mathrm{H}$ $=$ Height of the structure) as per IS456:2000

\subsubsection{Case ii (f): Wind Speed at $55 \mathrm{~m} / \mathrm{sec}$.}

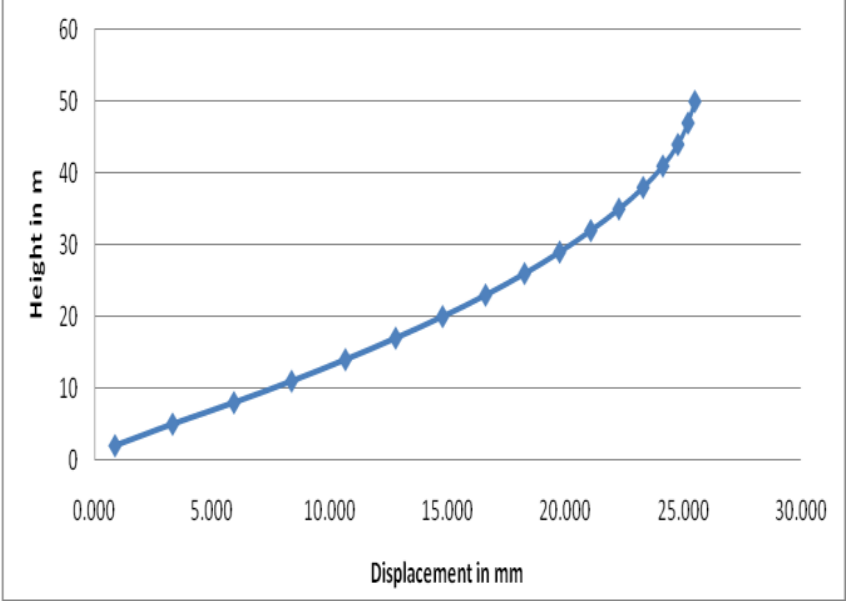

Chart-12: Displacements Vs Height for G+ 15 frame with vertical discontinuity at $55 \mathrm{~m} / \mathrm{sec}$ wind speed

From the Chart-12, it was observed that maximum displacement of $25.516 \mathrm{~mm}$ occurs at top storey. It satisfied the requirement of permissible displacement (i.e., H/500, $\mathrm{H}$ $=$ Height of the structure) as per IS456:2000

\subsection{Comparison of Lateral Displacements of} Frames

Comparison of lateral displacements of frames with and without vertical discontinuity of columns for a frame of $\mathrm{G}+15$ at different wind speeds. 


\subsubsection{Comparison (i)(a): Wind Speed at $33 \mathrm{~m} / \mathrm{sec}$.}

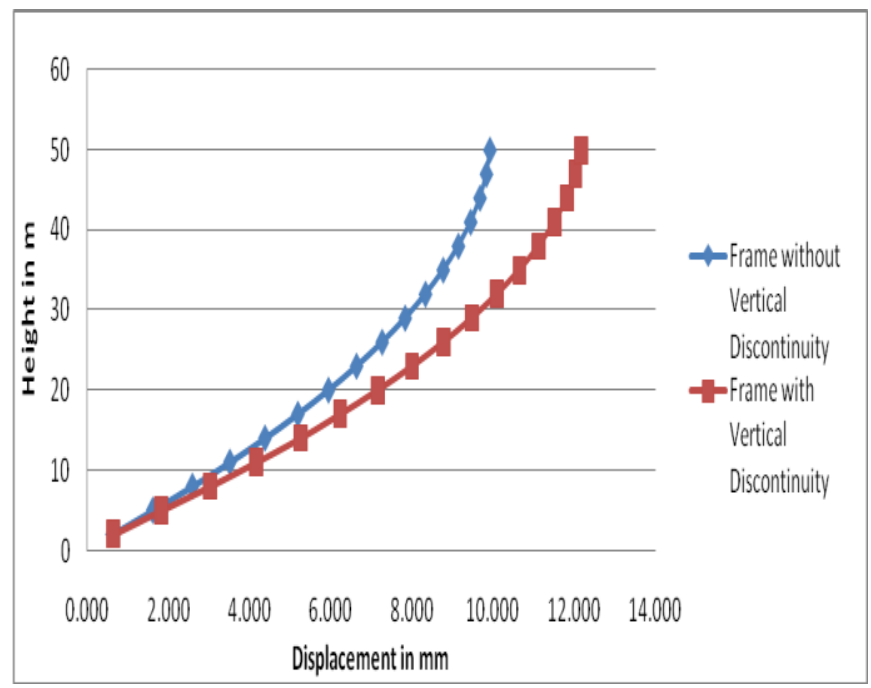

Chart-13: Comparison of displacements for $\mathrm{G}+15$ frames with and without vertical discontinuity of columns at 33 $\mathrm{m} / \mathrm{sec}$ wind speed

From the Chart-13, it was observed that there was an increase in $18 \%$ of lateral displacements in frame with vertical discontinuity of columns when compared to frame without vertical discontinuity of columns.

\subsubsection{Comparison (i)(b): Wind Speed at $39 \mathrm{~m} / \mathrm{sec}$.}

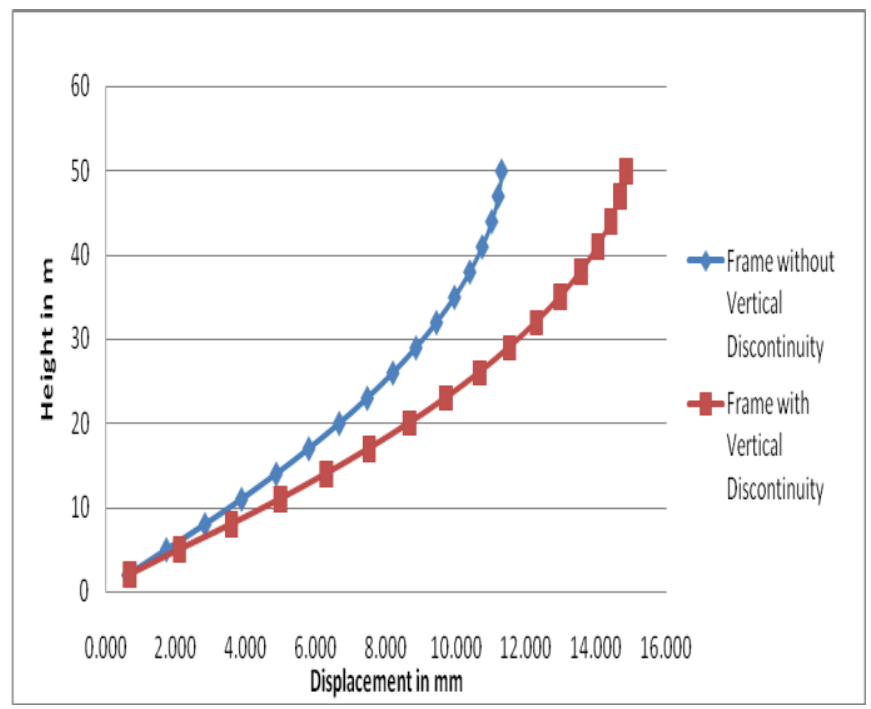

Chart-14: Comparison of displacements for G+ 15 frames with and without vertical discontinuity of columns at 39 $\mathrm{m} / \mathrm{sec}$ wind speed

From the Chart-14, it was observed that there was an increase in $24 \%$ of lateral displacements in frame with vertical discontinuity of columns when compared to frame without vertical discontinuity of columns.

\subsubsection{Comparison (i)(c): Wind Speed at $44 \mathrm{~m} / \mathrm{sec}$.}

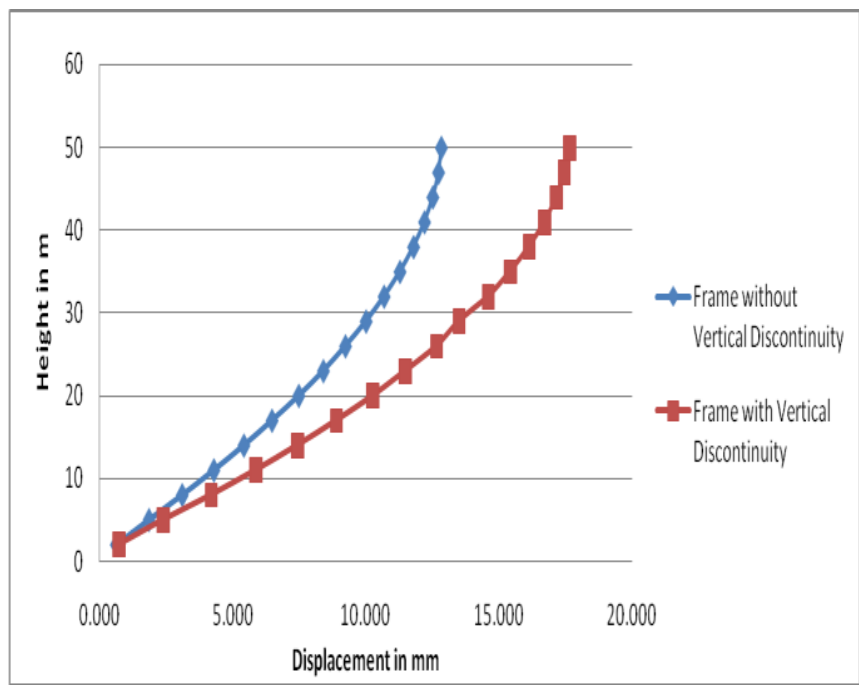

Chart-15: Comparison of displacements for $\mathrm{G}+15$ frames with and without vertical discontinuity of columns at 44 $\mathrm{m} / \mathrm{sec}$ wind speed

From the Chart-15, it was observed that there was an increase in $27 \%$ of lateral displacements in frame with vertical discontinuity of columns when compared to frame without vertical discontinuity of columns.

\subsubsection{Comparison (i)(c): Wind speed at $47 \mathrm{~m} / \mathrm{sec}$.}

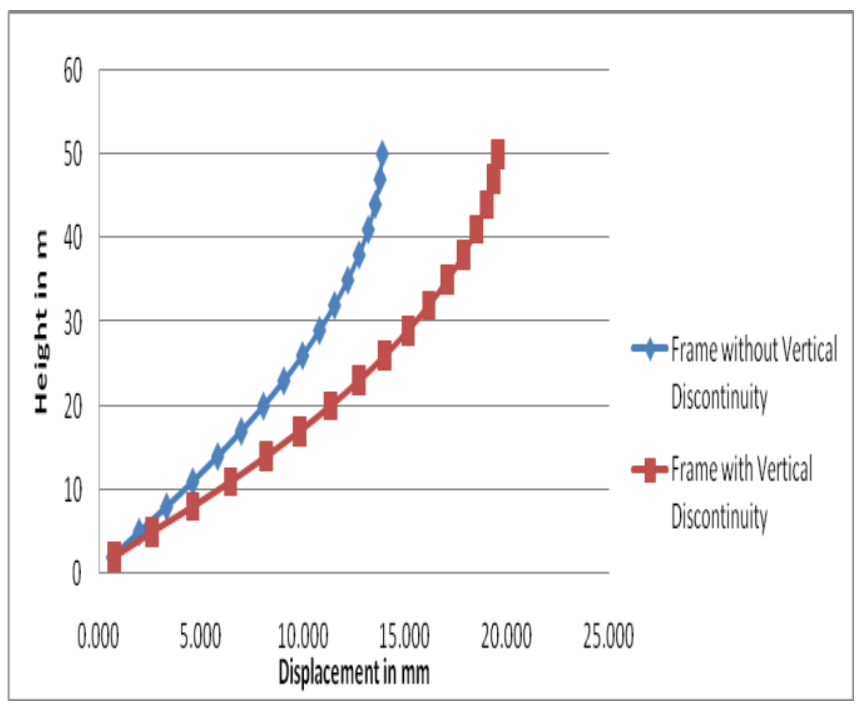

Chart-16: Comparison of displacements for G+ 15 frames with and without vertical discontinuity of columns at 47 $\mathrm{m} / \mathrm{sec}$ wind speed

From the Chart-16, it was observed that there was an increase in $29 \%$ of lateral displacements in frame with vertical discontinuity of columns when compared to frame without vertical discontinuity of columns. 


\subsubsection{Comparison (i)(d): Wind Speed at $50 \mathrm{~m} / \mathrm{sec}$.}

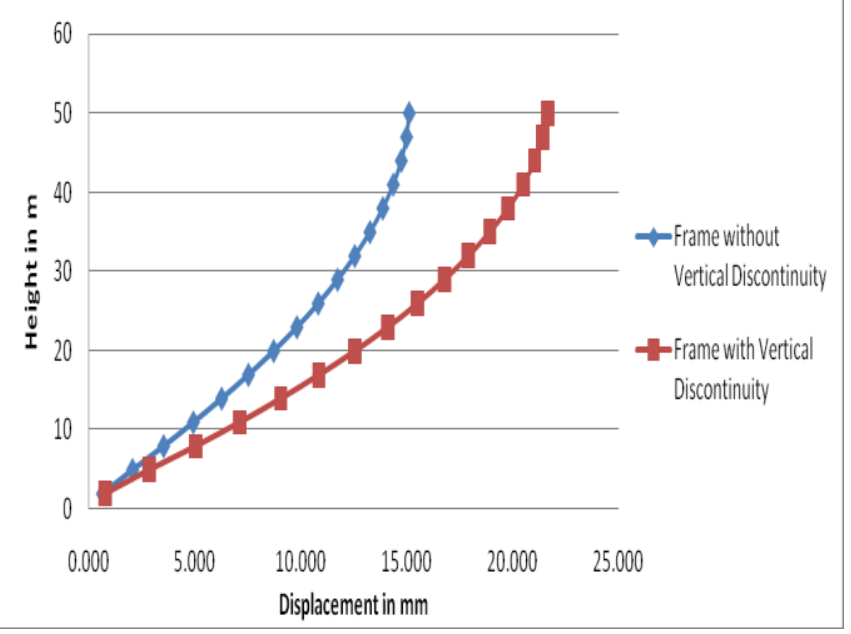

Chart-17: Comparison of displacements for $\mathrm{G}+15$ frames with and without vertical discontinuity of columns at 50 $\mathrm{m} / \mathrm{sec}$ wind speed

From the Chart-17, it was observed that there was an increase in $30 \%$ of lateral displacements in frame with vertical discontinuity of columns when compared to frame without vertical discontinuity of columns.

\subsubsection{Comparison (i)(e): Wind Speed at $55 \mathrm{~m} / \mathrm{sec}$.}

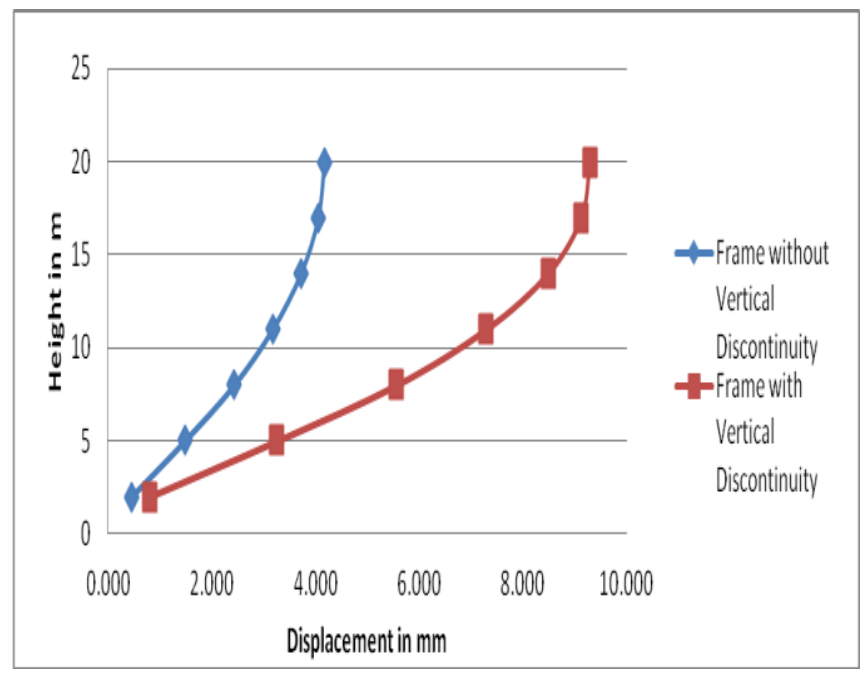

Chart-18: Comparison of displacements for $\mathrm{G}+15$ frames with and without vertical discontinuity of columns at 50 $\mathrm{m} / \mathrm{sec}$ wind speed

From the Chart-18, it was observed that there was an increase in $55 \%$ of lateral displacements in frame with vertical discontinuity of columns when compared to frame without vertical discontinuity of columns.

\subsection{Comparison of Quantity of Steel}

Comparison of quantities of steel in frames with and without vertical discontinuity of columns for $\mathrm{G}+15$ stories at different wind speeds.

\subsubsection{Comparison (i): Wind Speed at $33 \mathrm{~m} / \mathrm{sec}$.}

Table-4: Quantities of steel for frames with and without vertical discontinuity of columns at $33 \mathrm{~m} / \mathrm{sec}$ wind speed

\begin{tabular}{|l|l|l|}
\hline $\begin{array}{l}\text { No.of } \\
\text { storeys }\end{array}$ & $\begin{array}{l}\text { Frame without Vertical } \\
\text { Discontinuity (in tones) }\end{array}$ & $\begin{array}{l}\text { Frame with Vertical } \\
\text { Discontinuity(intones) }\end{array}$ \\
\hline 5 & 107.3484 & 103.6315 \\
\hline 10 & 241.0585 & 232.461 \\
\hline 15 & 391.6944 & 378.5349 \\
\hline
\end{tabular}

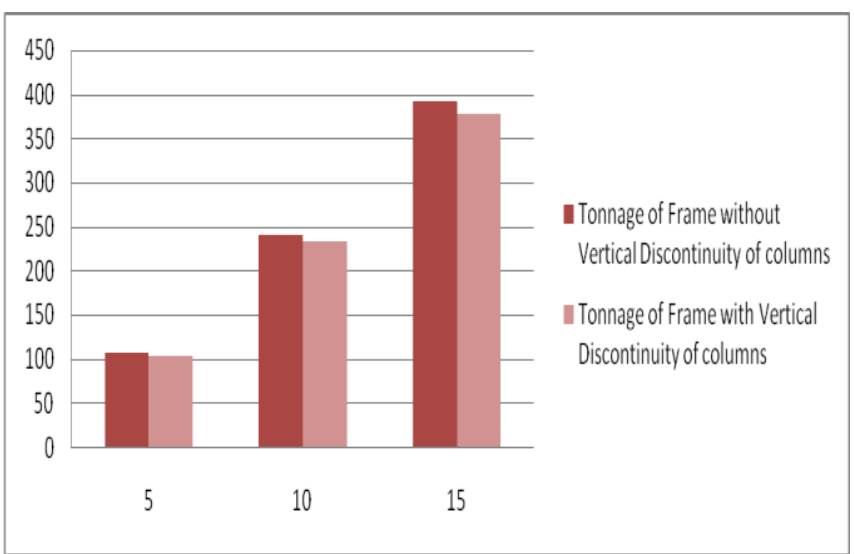

Chart-19: Comparison of quantities of steel for $\mathrm{G}+5, \mathrm{G}+10$, $\mathrm{G}+15$ frames with and without vertical discontinuity of columns at $33 \mathrm{~m} / \mathrm{sec}$ wind speed

From the Table-4, when compared to R.C space frame structure with vertical discontinuity of columns to without vertical discontinuity of columns, there was a slight decrease in percentage of steel of 3.46, 3.56 and 3.35 for $\mathrm{G}+5, \mathrm{G}+10$ $\& \mathrm{G}+15$ stories respectively at a basic wind speed of $33 \mathrm{~m} / \mathrm{s}$.

\subsubsection{Comparison (ii): Wind Speed at $39 \mathrm{~m} / \mathrm{sec}$.}

Table-5: Quantities of steel for frames with and without vertical discontinuity of columns at $39 \mathrm{~m} / \mathrm{sec}$ wind speed

\begin{tabular}{|l|l|l|}
\hline $\begin{array}{l}\text { No.of } \\
\text { storeys }\end{array}$ & $\begin{array}{l}\text { Frame without Vertical } \\
\text { Discontinuity (in tones) }\end{array}$ & $\begin{array}{l}\text { Frame with Vertical } \\
\text { Discontinuity(intones) }\end{array}$ \\
\hline 5 & 107.362 & 103.6613 \\
\hline 10 & 241.2228 & 232.6638 \\
\hline 15 & 392.4312 & 379.297 \\
\hline
\end{tabular}

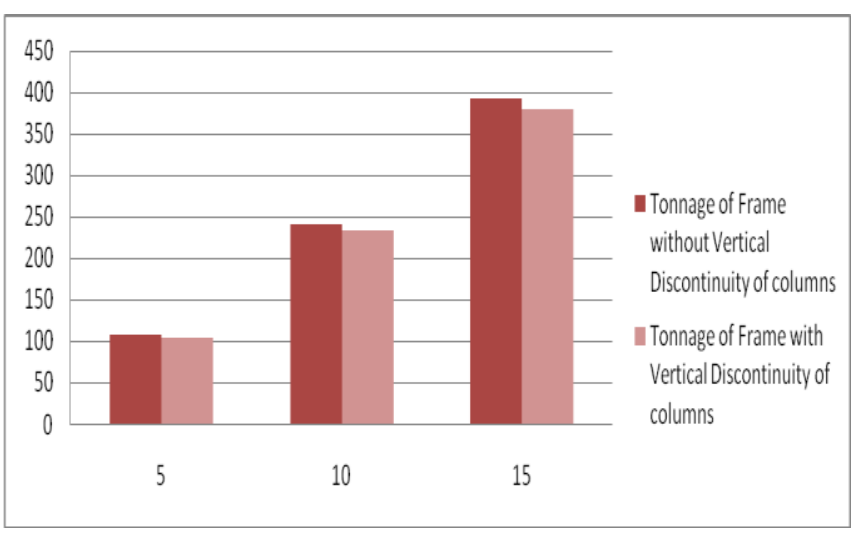

Chart-20: Comparison of quantities of steel for $\mathrm{G}+5, \mathrm{G}+10$, $\mathrm{G}+15$ frames with and without vertical discontinuity of columns at $39 \mathrm{~m} / \mathrm{sec}$ wind speed 
From the Table-5, when compared to R.C space frame structure with vertical discontinuity of columns to without vertical discontinuity of columns, there was a slight decrease in percentage of steel of $3.44,3.54$ and 3.34 for $\mathrm{G}+5, \mathrm{G}+10$ $\& \mathrm{G}+15$ stories respectively at a basic wind speed of $39 \mathrm{~m} / \mathrm{s}$.

\subsubsection{Comparison (iii): Wind Speed at $44 \mathrm{~m} / \mathrm{sec}$.}

Table-6: Quantities of steel for frames with and without vertical discontinuity of columns at $44 \mathrm{~m} / \mathrm{sec}$ wind speed

\begin{tabular}{|l|l|l|}
\hline $\begin{array}{l}\text { No.of } \\
\text { storeys }\end{array}$ & $\begin{array}{l}\text { Frame without Vertical } \\
\text { Discontinuity (in tones) }\end{array}$ & $\begin{array}{l}\text { Frame with Vertical } \\
\text { Discontinuity(intones) }\end{array}$ \\
\hline 5 & 107.3926 & 103.6992 \\
\hline 10 & 241.5467 & 232.9842 \\
\hline 15 & 393.7653 & 380.4803 \\
\hline
\end{tabular}

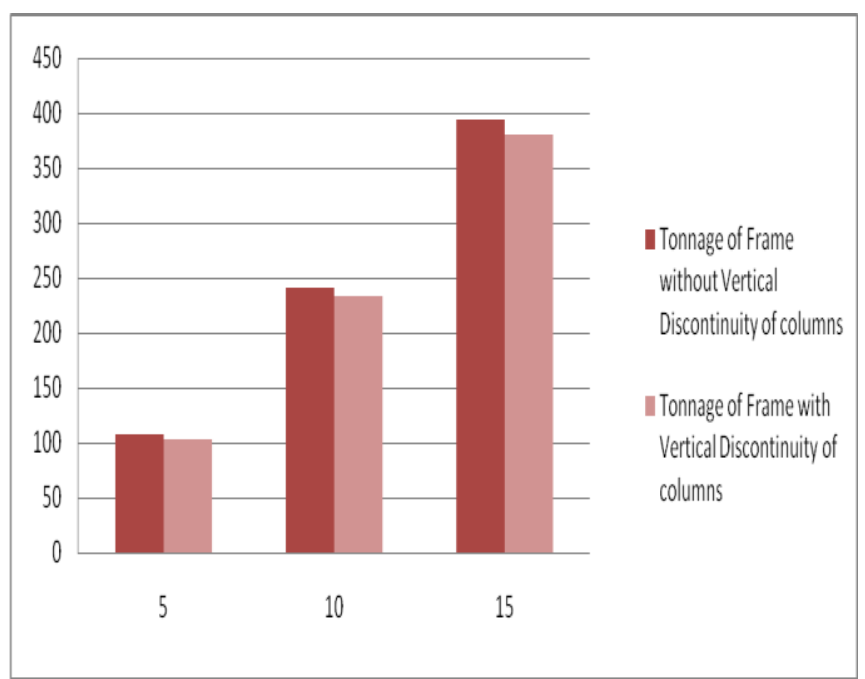

Chart-21: Comparison of quantities of steel for $\mathrm{G}+5, \mathrm{G}+10$, $\mathrm{G}+15$ frames with and without vertical discontinuity of columns at $44 \mathrm{~m} / \mathrm{sec}$ wind speed

From the Table-6, when compared to R.C space frame structure with vertical discontinuity of columns to without vertical discontinuity of columns, there was a slight decrease in percentage of steel of $3.43,3.54$ and 3.37 for $\mathrm{G}+5, \mathrm{G}+10$ $\& \mathrm{G}+15$ stories respectively at a basic wind speed of $44 \mathrm{~m} / \mathrm{s}$.

\subsubsection{Comparison (iv): Wind Speed at $47 \mathrm{~m} / \mathrm{sec}$.}

Table-7: Quantities of steel for frames with and without vertical discontinuity of columns at $47 \mathrm{~m} / \mathrm{sec}$ wind speed

\begin{tabular}{|l|l|l|}
\hline $\begin{array}{l}\text { No.of } \\
\text { storeys }\end{array}$ & $\begin{array}{l}\text { Frame without Vertical } \\
\text { Discontinuity (in tones) }\end{array}$ & $\begin{array}{l}\text { Frame with Vertical } \\
\text { Discontinuity(intones) }\end{array}$ \\
\hline 5 & 107.4036 & 103.7315 \\
\hline 10 & 241.7888 & 233.155 \\
\hline 15 & 394.9438 & 381.6974 \\
\hline
\end{tabular}

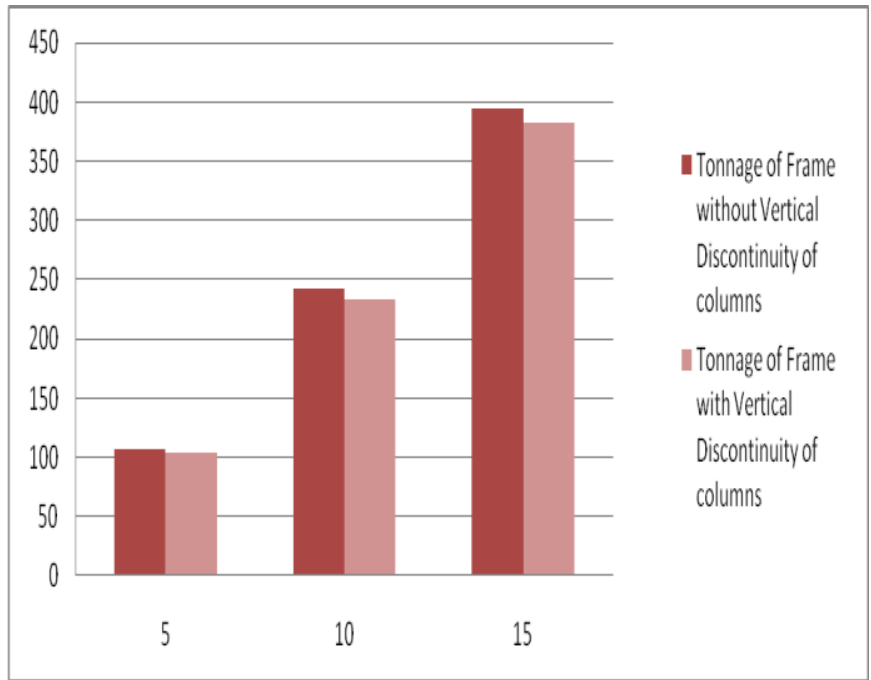

Chart-22: Comparison of quantities of steel for $\mathrm{G}+5, \mathrm{G}+10$, $\mathrm{G}+15$ frames with and without vertical discontinuity of columns at $47 \mathrm{~m} / \mathrm{sec}$ wind speed

From the Table-7, when compared to R.C space frame structure with vertical discontinuity of columns to without vertical discontinuity of columns, there was a slight decrease in percentage of steel of $3.41,3.57$ and 3.35 for $\mathrm{G}+5, \mathrm{G}+10$ $\& \mathrm{G}+15$ stories respectively at a basic wind speed of $47 \mathrm{~m} / \mathrm{s}$.

\subsubsection{Comparison (v): Wind Speed at $50 \mathrm{~m} / \mathrm{sec}$.}

Table-8: Quantities of steel for frames with and without vertical discontinuity of columns at $50 \mathrm{~m} / \mathrm{sec}$ wind speed

\begin{tabular}{|l|l|l|}
\hline $\begin{array}{l}\text { No.of } \\
\text { storeys }\end{array}$ & $\begin{array}{l}\text { Frame without Vertical } \\
\text { Discontinuity (in tones) }\end{array}$ & $\begin{array}{l}\text { Frame with Vertical } \\
\text { Discontinuity(intones) }\end{array}$ \\
\hline 5 & 107.4349 & 103.8173 \\
\hline 10 & 241.9876 & 233.528 \\
\hline 15 & 396.0297 & 383.0263 \\
\hline
\end{tabular}

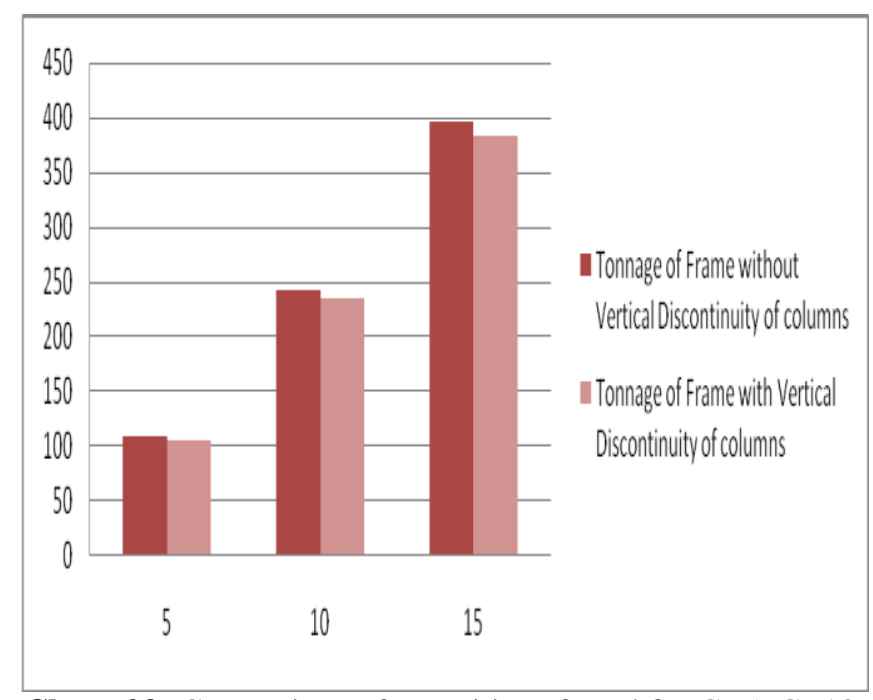

Chart-23: Comparison of quantities of steel for $\mathrm{G}+5, \mathrm{G}+10$, $\mathrm{G}+15$ frames with and without vertical discontinuity of columns at $50 \mathrm{~m} / \mathrm{sec}$ wind speed 
From the Table- 8 , when compared to R.C space frame structure with vertical discontinuity of columns to without vertical discontinuity of columns, there was a slight decrease in percentage of steel of $3.36,3.49$ and 3.28 for $\mathrm{G}+5, \mathrm{G}+10$ $\& \mathrm{G}+15$ stories respectively at a basic wind speed of $50 \mathrm{~m} / \mathrm{s}$.

\subsubsection{Comparison (vi): Wind Speed at $55 \mathrm{~m} / \mathrm{sec}$.}

Table-9: Quantities of steel for frames with and without vertical discontinuity of columns at $55 \mathrm{~m} / \mathrm{sec}$ wind speed

\begin{tabular}{|l|l|l|}
\hline $\begin{array}{l}\text { No.of } \\
\text { storeys }\end{array}$ & $\begin{array}{l}\text { Frame without Vertical } \\
\text { Discontinuity (in tones) }\end{array}$ & $\begin{array}{l}\text { Frame with Vertical } \\
\text { Discontinuity(intones) }\end{array}$ \\
\hline 5 & 107.4737 & 103.8173 \\
\hline 10 & 242.312 & 233.8533 \\
\hline 15 & 397.6877 & 385.816 \\
\hline
\end{tabular}

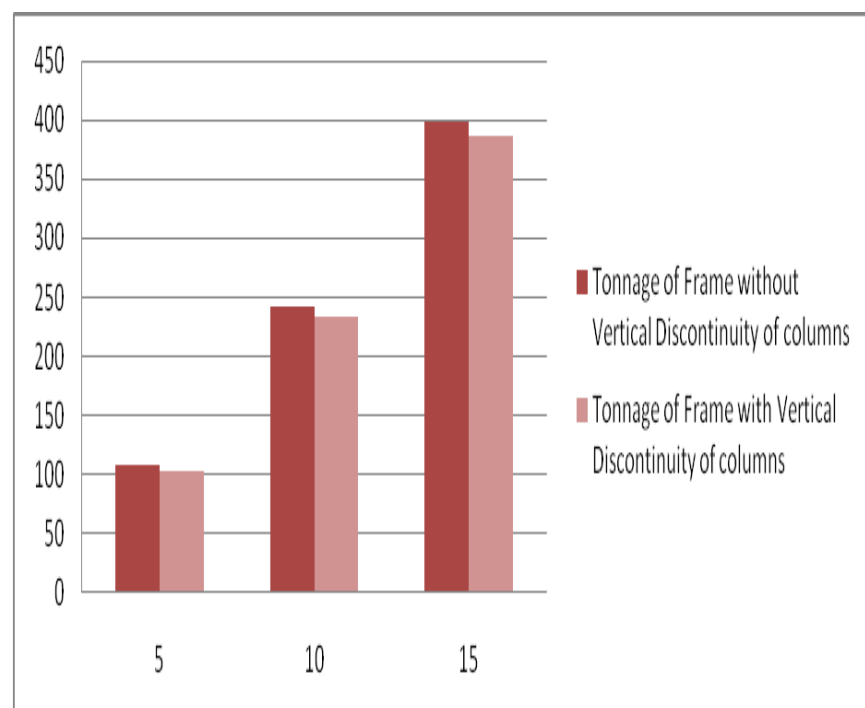

Chart-24: Comparison of quantities of steel for $\mathrm{G}+5, \mathrm{G}+10$, $\mathrm{G}+15$ frames with and without vertical discontinuity of columns at $55 \mathrm{~m} / \mathrm{sec}$ wind speed

From the Table-9, when compared to R.C space frame structure with vertical discontinuity of columns to without vertical discontinuity of columns, there was a slight decrease in percentage of steel of 3.46, 3.56 and 3.35 for $\mathrm{G}+5, \mathrm{G}+10$ $\& \mathrm{G}+15$ stories respectively at a basic wind speed of $55 \mathrm{~m} / \mathrm{s}$.

\section{CONCLUSION}

The lateral displacements and quantities of steel for R.C framed structures with and without vertical discontinuity were investigated using the linear static analysis. Following were the major conclusions drawn from the study.

1. For G+15 storey building, it was observed, when compared to frame without vertical discontinuity of columns to with vertical discontinuity of columns, there was an increase of percentage of lateral displacements of 18, 24, 27, $29,30 \& 32$ for basic wind speeds of $33,39,44,47,50 \& 55$ respectively.

4. It was observed, when compared to frame without vertical discontinuity of columns to with vertical discontinuity of columns, there was aonly slight decrease in percentage of steel ranges from 3.28 to 3.35 for all the considered frames at all basic at all basic wind speeds which does not influence the economy of the structure.

5. From the pilot study, it was concluded that frames without vertical discontinuity of the columns having more stiffness when compared to frames with vertical discontinuity of columns.

\section{REFERENCES}

[1]. Athanassiadou C.J, 2008, Seismic performance of R/C plane frames irregular in elevation, Engineering Structures 30 (2008):1250-1261.

[2]. Das, S and Nau, J.M.(2003). Seismic design aspects of vertically irregular reinforced concrete buildings, Earthquake Spectra,19, 3, 455-477.

[3]. Haijuan Duana, Mary Beth D. Hueste, 2012, Seismic performance of a reinforced concrete frame building in China, Engineering Structures 41 (2012):77-89.

[4]. IS 456:2000, "Indian Standard plain and reinforced concrete-Code of Practice", Bureau of Indian Standards, New Delhi, 2000.

[5]. IS: 875 (Part 1), "Indian Standard Code of Practice for design loads for building and structures, Dead Loads" Bureau of Indian Standards, New Delhi.

[6]. IS: 875 (Part 2), "Indian Standard Code of Practice for design loads for building and structures, Live Loads" Bureau of Indian Standards, New Delhi.

[7]. IS: 875 (Part 3), "Indian Standard Code of Practice for design loads (Other than earthquake) for building and structures, Wind Loads" Bureau of Indian Standards, New Delhi.

[8]. Karavallis, Bazeos and Beskos, 2008, Estimation of seismic inelastic deformation demands in plane steel MRF with vertical mass irregularities, Engineering Structures 30 (2008) 3265-3275.

[9]. Lee Han Seon ,Dong Woo Kee, 2007, Seismic response characteristics of high-rise RC wall buildings having different irregularities in lower stories, Engineering Structures 29 (2007):3149-3167.

[10]. Michalis, F., Vamvatsikos, D., and Monolis, P. (2006) "Evaluation of the influence of vertical irregularities on the seismic performance of a nine-storey steel frame".

Earthquake Engineering and Structural Dynamics. 35:14891509.

[11]. Poonam, Kumar Anil and Gupta Ashok K, 2012, Study of Response of Structural Irregular Building Frames to Seismic Excitations, International Journal of Civil, Structural, Environmental and Infrastructure Engineering Research and Development (IJCSEIERD), ISSN 2249-6866 Vol.2, Issue 2 (2012) 25-31.

[12]. Sadjadi R, Kianoush M.R. , Talebi S , 2007, Seismic performance of reinforced concrete moment resisting frames, Engineering Structures 29 (2007):2365-2380.

[13]. Sarkar P, Prasad A Meher, Menon Devdas, 2010, Vertical geometric irregularity in stepped building frames, Engineering Structures 32 (2010) 2175-2182.

[14]. Shahrooz Bahrain M. and Moehle Jack P., Seismic Response And Design of Setback Buildings- Journal of Structural Engineering, Vol. 116, No. 5, May, 1990 14231439. 
[15]. Valmundsson and Nau, 1997, Seismic Response of Building Frames with Vertical Structural Irregularities, Journal of structural engineering, 123:30-41.

\section{BIOGRAPHIES}

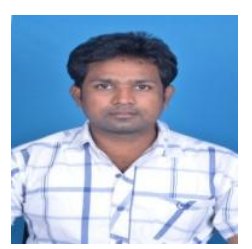

Sri.M.Pavan Kumar, M.E (S.E.N.D.M), $(\mathrm{PhD})$, Assistant Professor in Civil Engineering Department, S.V.P Engineering College, Visakhapatnam. He is doing $\mathrm{PhD}$ in Andhra university and Licensed Structural Consultant in Visakhapatnam. He has published several research papers in various journals.

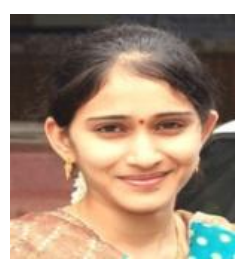

Singuri Sirisha is currently M.E Research scholar in Civil Engineering Department at S.V.P Engineering College, Visakhapatnam. 